\title{
Т.Н. Савинова
}

\section{Библиотеки военно-учебных заведений Оренбурга (середина XVIII в. - 1918 г.)}

Реферат. C середины XVIII в. до 1918 г. Оренбург был крупным военным центром, что во многом определяло его социокультурное пространство. Подготовка кадров для местных канцелярии и гарнизона в городе осуществлялась несколькими военно-образовательными учреждениями. В силу сложившихся исторических обстоятельств до нашего времени сохранились далеко не все документы об учебных заведениях и их учебно-вспомогательных подразделениях, к которым относятся и библиотеки. Целью работы является обобщение имеющегося в настоящее время материала по истории библиотек военноучебных заведений Оренбурга. Часть документов вводится в научный оборот впервые.

Ключевые слова: военно-учебные заведения, библиотеки, история библиотек, Оренбургская школа военных кантонистов, Оренбургский Неплюевский кадетский корпус, Второй оренбургский кадетский корпус, Оренбургское казачье юнкерское училище, Оренбургская школа прапорщиков пехоты.

Для цитирования: Савинова T.Н. Библиотеки военно-учебных заведений Оренбурга (середина XVIII в. - 1918 г.) // Библиотековедение. 2017. Т. 66, № 1. С. 77-86.

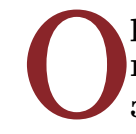

ренбург был основан в 1743 году. Освоение новых территорий требовало присутствия значительного воинского контингента, а удаленность от крупных городов - начальной, пусть даже самой низшей, подготовки на месте некоторых категорий специалистов. С середины XVIII в. до 1918 г. в городе в разное время работали несколько военных учебных заведений, сведений о значительной части которых обнаружено немного. Причина утраты многих документов, на наш взгляд, в том, что в 1917-1919 гг. город несколько раз находился под управлением то войск атамана оренбургского казачества А.И. Дутова, то Красной армии, затем пять лет был столицей Киргизской (Казахской) ACСР, с последующим разделением архивов, библиотек, музеев и пр. В эти годы часть архивов, в том числе военных, была уничтожена $[1 ; 2]$. Но надежда, что удастся найти неизвестные пока документы и о самих военных учебных заведениях Оренбурга, и об их библиотеках, остается.

\section{Первые военные образовательные учреждения Оренбурга}

Планируя открыть школы в новом городе, руководитель Оренбургской экспедиции

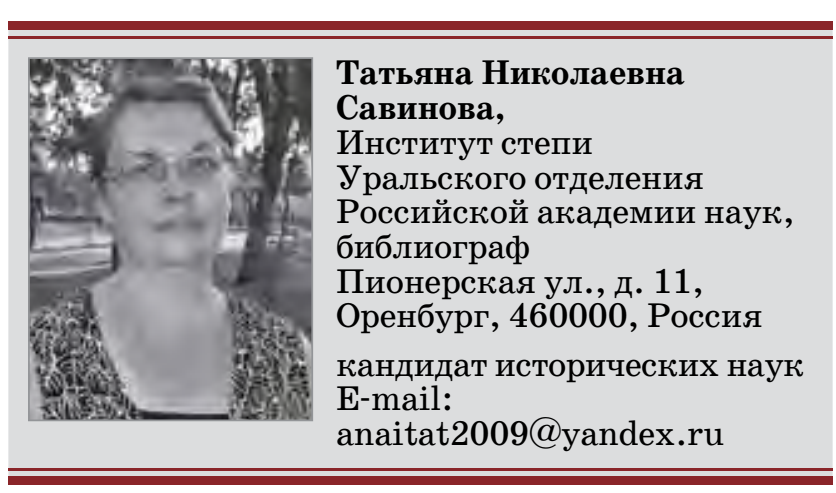

И.К. Кирилов заказал для них книги. В росписи инструментам и книгам, необходимым для строящегося Оренбурга, значится: «для учеников - азбук немецких, французских, латинских в 20 экз.; для учеников же - книг риторических, и исторических, и поэтических, библии немецкие, французские, латинские с толкованиями и с корконданциями» [3]. Но заказанная литература дошла только до Самары, откуда тогда осуществлялось руководство освоением Оренбургского края. В 1737 г. И.К. Кирилов умер, сменивший его В.Н. Татищев перенаправил книги в Екатеринбург для комплектования библиотек уже существовавших школ [4]. Через несколько лет в 
новом Оренбурге появились первые школы, о которых известно очень мало. С 1745 или 1746 г. по 1760 г. существовала школа лладших военных инженеров. Десять учащихся изучали геометрию, арифметику и части фортификации. По окончании курса слушатели производились в кондукторы. В 1760 г. П.И. Шувалов подал прошение в Сенат о том, что в основанной им петербургской Соединенной Артиллерийской и Инженерной дворянской школе курс обучения намного шире, чем в Оренбурге, поэтому «оренбургских надобно определить в здешнюю соединенную школу, дабы оные могли начатые науки окончить и прочим обучиться» [5]. Сенат согласился, и ученики были переведены в Санкт-Петербург. На данном этапе истории библиотечного дела Оренбурга можно говорить, скорее всего, только о возможном наличии библиотеки учебников или учебных пособий.

Следующими военными образовательными учреждениями на территории Оренбургской губернии стали школы военных кантонистов. Ими назывались дети солдат и унтер-офицеров, приписанные к военному ведомству. В 1826 г. военносиротские отделения были преобразованы в роты и батальоны военных кантонистов, где обучали грамоте и военному делу. Существовали также специальные кантонные школы: артиллерийские, инженерные, аудиторская, военно-медицинская, топографов и др. В Оренбургской губернии данные преобразования произошли при генерал-губернаторе П.К. Эссене (1772-1844). В 1827 г. возникли Оренбургский (2 тыс. учеников) и Троицкий (1 тыс. учеников) батальоны военных кантонистов, Верхнеуральский и Звериноголовский полубатальоны (500 учеников); Кизильское и Орское отделения были ликвидированы с переводом кантонистов в Оренбургский батальон. В кантонисты зачислялись десятилетние дети, в течение пяти лет они учились в классах, с 15 до 18 лет поступали в линейные батальоны. Для классного обучения при батальонах Оренбургской военно-пограничной линии имелось 12 школ. По их окончании военные кантонисты рассылались по армейским полка́м и учреждениям [6]. В 1859 г. эта оренбургская школа была преобразована в училище военного ведомства; в 1866 г. оно получило новое название - военно-начальная школа (в документах ее называют 4 военным училищем [7, оп. 1, д. 155]); затем оно получило статус военной прогимназии, которую упразднили в 1888 г., оставшихся учеников перевели в Ярославскую военную школу [8, с. 43].

Сведений о библиотеках этих учебных заведений пока не обнаружено. В 1874 г. дела и приказы Оренбургской прогимназии были утрачены [7, оп. 1, д. 181]. Из сохранившихся послужных списков топографов, выпускников школы военных кантонистов, известно, что они учили Закон Божий, арифметику, грамматику, алгебру до уравнения 2-й или 3-й степени (в зависимости от способностей), геометрию, российскую географию, инструментальную и глазометрическую съемку, черчение планов [9]. Можно предположить, что библиотека учебников и учебных пособий все же существовала и имела книги по этим предметам.

\section{Библиотека Оренбургското Неплюевското кадетского корпуса}

9 февраля 1824 г. (ст. ст.) было высочайше утверждено постановление об учреждении в Оренбурге военного училища, 2 января 1825 г. оно было открыто и названо именем основателя края И.И. Неплюева (1693-1773) [10, с. 385]. Училище несколько раз меняло свое название: Оренбургский Неплюевский кадетский корпус (1844-1867), Оренбургская Неплюевская военная гимназия (1867-1882), вновь Оренбургский Неплюевский кадетский корпус (1882-1919).

За годы работы это учебное заведение выпустило множество выдающихся офицеров, переводчиков, чиновников, снискавших себе славу на поприще служения Отечеству. Более 70 его воспитанников дослужились до генералов.

Здесь был основан первый в Оренбургском крае музей (1830). Его хранителями являлись сотрудники военного училища, в том числе библиотекари А.М. Аничков и А.Ф. Викстрем. Причем A.M. Аничков занимался также исследовательской работой - с 1843 г. до второй половины 1860-х гг. вел в Оренбурге метеорологические наблюдения, значение которых для науки было высоко оценено Главной физической обсерваторией [7, оп. $1-2$, д. 62 ; оп. 1 , д. 149 , л. 96-100].

Создание Оренбургского Неплюевского военного училища положило начало полному среднему и профессиональному образованию в городе. В него для обучения принимали детей офицеров иррегулярных войск Отдельного оренбургского корпуса, «азиатцев» и «всякого свободного сословия» [10, с. 385]. Помимо обязательных предметов: истории, географии, естествознания, математики, основ военных наук и других дисциплин, в училище преподавались восточные языки, так как имелась постоянная потребность в переводчиках [10, с. 385-388].

Как и в других подобных учебных заведениях, в оренбургском было несколько библиотек: фундаментальная (в основном для преподавателей и воспитанников старших классов), ученические (состояли из книг для внеклассного чтения учащихся) и учебные (включали фонд учебной литературы). Подробнее структура библиотек военно-учебных заведений и документы, регламентировавшие их работу, рассмотрены в работе М.А. Бондаренко [11, с. 20].

Библиотека была создана в 1825 г., но, как отмечалось в отчете, составленном в 1903 г. [12, л. 89 об.], значительно пополняться начала только с 1860-х годов. Комплектование шло традиционно для того времени: через покупку изданий и выписку из других городов, из Штаба военно-учебных 
заведений, путем пожертвований. Поскольку в документах, как правило, давалось краткое и не всегда точное библиографическое описание книг, сейчас можно только с большей или меньшей долей вероятности предполагать, какие именно книги имелись в библиотеках. Так, по данным Г.П. Матвиевской [13, с. 180], в 1828 г. директором училища Г.Ф. Генсом (1787-1845), являвшимся одновременно председателем Оренбургской пограничной комиссии, в учебное заведение были переданы два тома некоего «Лексикона турецкого, арабского и персидского языков с переводом на латинский язык и с помещением употребительных немецких, французских, итальянских и польских выражений», ненужные в Комиссии, но которые могли быть полезны преподавателям и кадетам при изучении восточных языков; в 1829 г. ханом Внутренней Орды Бокей-Ханом - два словаря восточных языков, полученные им из Константинополя; губернатором П.К. Эссеном - атлас Франции, планы нескольких немецких крепостей и 11 книг, в том числе сочинение Э.А. Эверсмана «Путешествие из Оренбурга в Бухару». С разрешения губернатора для библиотеки были приобретены 10 экз. «Атласа Российского государства». По инициативе следующего губернатора П.П. Сухтелена (1788-1833) в 1831 г. был куплен «Атлас древнего света, состоящий из 23 карт с объяснительными таблицами и составленный Императорского Санкт-Петербургского университета адъюнкт-профессором Александром Брутом» и другие книги. Сам П.П. Сухтелен передал училищному комитету «для чтения воспитанников и затем для помещения в библиотеку училища» присланную ему книгу А.И. Левшина «Описание киргиз-казачьих, или киргиз-кайсацких орд и степей» .

Специально для воспитанников по поручению и под руководством П.П. Сухтелена чиновником по особым поручениям И.В. Зћуковским было написано «Краткое обозрение достопамятных событий Оренбургского края, расположенных хронологически с 1246 по 1832 год», вышедшее в 1832 г. в Санкт-Петербурге и Оренбурге. Вне всякого сомнения, некоторая часть оренбургского тиража должна была пополнить библиотеку учебного заведения. По желанию П.П. Сухтелена книга была переведена на татарский язык воспитанниками азиатского отделения под руководством учителя М.И. Иванова, работу завершили в 1835 году $[13$, c. 181].
В 1836 г. известный мореплаватель адмирал И.Ф. Крузенштерн, узнав о бедности библиотечного фонда Оренбургского военного училища, прислал в дар книги, изданные в Морском кадетском корпусе Санкт-Петербурга в течение предшествовавших восьми лет и экземпляр своего труда о путешествии вокруг света, всего десять названий [14, д. 4606Б, л. 1-2].

В 1839 г. через Штаб военно-учебных заведений были выписаны 10 экз. книги И.К. Кайданова «Обзор всеобщей истории, или Указание на главнейшие события, случившиеся в свете от сотворения мира до наших времен», 2 экз. журнала «Новое детское чтение», 2 экз. альманаха «Утренняя заря», 30 экз. «Журнала для чтения воспитанникам военно-учебных заведений», 20 экз. первого тома учебного пособия «Жиивописный мир, или Взгляд на природу, науки, искусства и человека» Ф.А. Кони, 12 экз. учебника Н.Г. Устрялова «Начертания русской истории» и т. д. [14, д. 4693 , л. 129 об., 131 об., 132 об.]. Как видим, руководители училища стремились пополнять библиотеку и обеспечивать внеклассное чтение кадетов в соответствии с требованиями времени.

К сожалению, не обнаружено делопроизводственной документации самих библиотек, поэтому любая находка представляет ценность.

В 1843 г., по данным отчета о состоянии Оренбургского Неплюевского военного училища, «библиотека, учебные припасы и пособия <...> занимали одну небольшую комнату, которая вместе служила присутственным местом Комитета, приемной для посетителей и сборною комнатою учителей и чиновников» [7, оп. $1-2$, д. 62 , л. 13 об.]. В конце 1840-х гг. был составлен план реконструкции здания, в котором отводилось место и для библиотеки [14, д. 5629].

Приоритетным при комплектовании библиотеки, принимая во внимание выделение денеж- 
ных средств, являлось приобретение учебников и учебных пособий (книг и журналов для внеклассного чтения закупалось примерно в два раза меньше) [14, д. 4693, л. 129 об., 131 об., 132 об.].

Ф.И. Лобысевич в книге «Город Оренбург» писал, что на 1878 г. «бесспорно лучшая и полнейшая библиотека» в городе была в военной гимназии (так в 1867-1882 гг. назывался корпус). «Отличное содержание, порядок, выбор книг и полнота этой библиотеки могут поставить ее наряду с лучшими библиотеками; очень жаль только, что она не предоставлена пользованию общества и составляет, как мебель, исключительную принадлежность гимназии». А далее он отмечал, что абонементная плата за право чтения была бы выгодна и обществу, и данной библиотеке [15, с. 10]. Но общественной она, естественно, так и не стала.

Работу библиотек военно-учебных заведений регламентировало множество нормативных документов, в том числе «Циркуляр по военно-учебным заведениям» от 16 декабря 1866 г. [16], определявший репертуар книг и учебных пособий, необходимых в учебном процессе [17, с. 104], «Инструкция по содержанию библиотек военно-учебных заведений, подведомственных Главному их управлению» [18], определявшая порядок пополнения библиотек, хранения книг и выдачи их для чтения, ведения описей и каталогов. В 1885 г. был издан первый «Каталог книг для чтения воспитанников военных учебных заведений». В «Положении о кадетских корпусах, высочайше утвержденном 14 февраля 1886 г.» предписывалось в каждом кадетском корпусе иметь «общую и ротную библиотеки, физический кабинет и коллекции учебных пособий по всем предметам установленного курса» [19, с. 26], «исправное содержание и целесообразное пополнение библиотек» возлагалось на инспектора классов $[19$, с. 33].

Фундаментальная библиотека Оренбургского чрез оное море и путешествии до г. Дербента. Сочинено в 1728 году»; «Судебник государя царя и великого князя Иоанна Васильевича...» [21]; рукопись, озаглавленная «О путешествии Гумбольдта по России до прибытия к горе Благодатной» и др.

В ротных библиотеках (до 1882 г. они назывались «возрастные»), предназначенных для внеклассного чтения учащихся, находилось 908 названий в 2356 томах. Учебников и учебных пособий по разным отраслям знаний было 12426 экз., кроме того имелись учебные руководства по «разным отделам искусств» (рисованию, пению и музыке, гимнастике, фехтованию, столярному и токарному делу) в количестве 3499 экземпляров [22, с. 113].

В 1903 г. библиотека Оренбургского Неплюевского кадетского корпуса имела 35249 экз. книг (87 экз. из которых были на восточных языках) и несколько рукописей. Библиотекарями велись «рукописные, алфавитные и картотечные в ящиках» каталоги [12, л. 89 об. - 90].

В здании учебного заведения находилась домовая Воскресенская церковь. «Центральная часть корпуса, обращенная к западу, - сообщалось в “Путеводителе по городу Оренбургу” П.Д. Райского, - занята довольно обширной церковью, в которой имеется особая библиотека, заключающая в себе более 700 экземпляров книг духовно-нравственного содержания» [23, с. 120-121].

Из мероприятий, прививающих стремление к чтению, можно назвать проводившиеся в корпусе литературные вечера.

\section{Оренбургское военное/казачье юнкерское училиче}

В 1867 г. по ходатайству генерал-губернатора Н.А. Крыжановского (1818-1888) открылось Оренбургское военное юнкерское училище, переименованное затем в казачье юнкерское училище (1878),

Неплюевского кадетского корпуса в 1891 г. имела 7879 названий книг и рукописных сочинений в 24199 томах, среди которых было несколько уникальных: «География генеральная, небесный и земноводный круги, купно с их свойствы и действы, в 3 томах описующая» Б. Варения (Варениуса) [20], список с труда Ф.И. Соймонова «Екстракт журналов мореплавания по Каспийскому морю, которое происходило в 1715 , $1716,1718,1719,1720$ и 1727 гг., при том описание же о высокославном государя императора Петра Великого походе в Астрахань

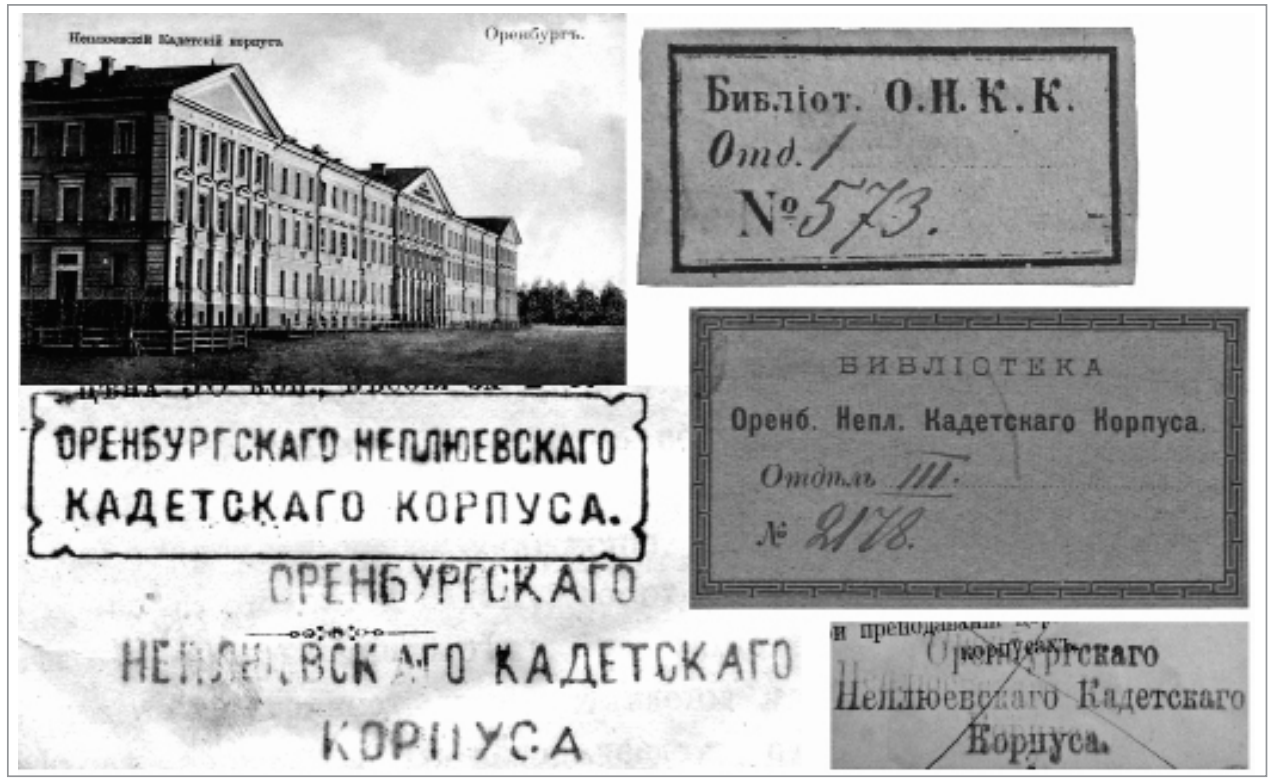

Булажные ярльки и штелпели библиотек

Оренбургского Неплюевского кадетского корпуса 


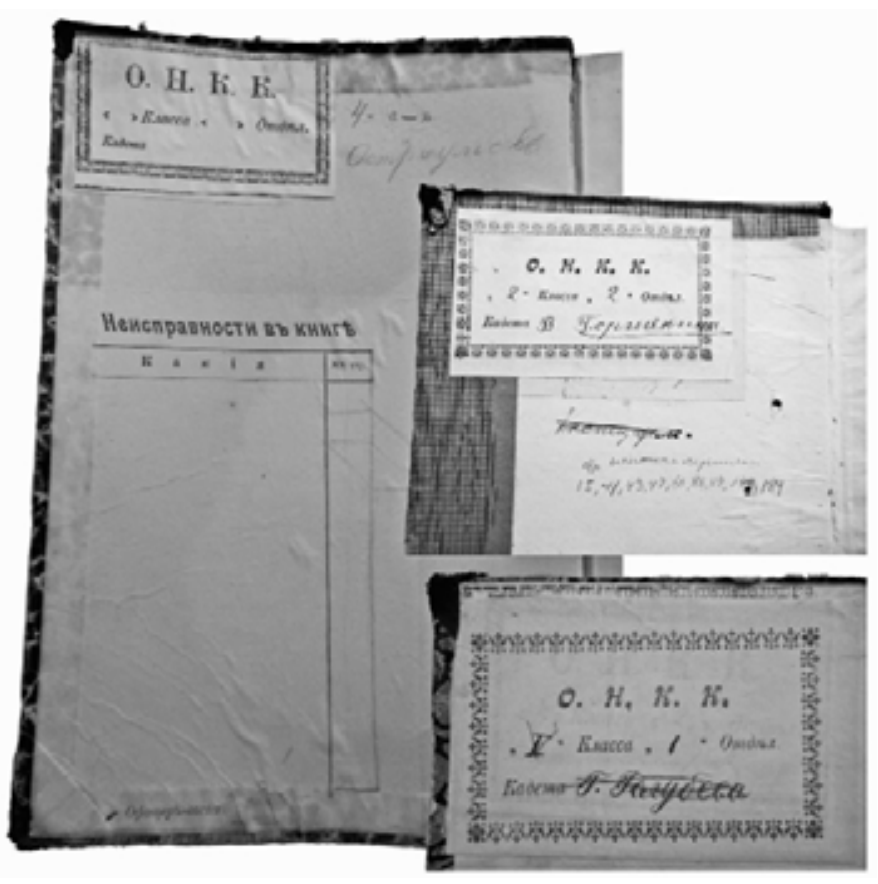

Вторые страницы обложек книг с полеткали об их состоянии и бумажныли ярлыками

военное казачье училище (1910), с целью подготовки офицеров для всех казачьих войск России, кроме Донского, имевшего свое училище в Новочеркасске. Срок обучения составлял два года. При училище имелся приготовительный класс для взрослых малограмотных казаков. Сословных ограничений при поступлении не устанавливалось. В 1901 г. училище стало трехклассным и в него перевели казачий отдел Иркутского юнкерского училища.

За историю работы училища его возглавляли восемь начальников: полковник В.П. Котов (1867-1870), полковник В.А. Потто (1870-1881), Генерального штаба полковник Ф.К. Гершельман $(1881-1885)$, полковник М.А. Козловский (1885-1890), полковник Э.С. Муромцев (18901895), Генерального штаба полковник В.В. Григоров (1895-1902), Генерального штаба полковник М.Г. Михеев (1902-1907) и Генерального штаба полковник К.М. Слесарев (1908-1920) [24, с. 302].

У нас нет данных о начале создания библиотеки, но в 1868 г. для нее были выписаны книги из книжного магазина Я.А. Исакова (СанктПетербург) [25, л. 561-563]. В списке предназначенных юнкерскому училищу изданий значились произведения А. Гумбольдта «Космос. Опыт физического мироописания» и «Картины природы с научными объяснениями», 11 томов «Истории России с древнейших времен» С.М. Соловьева, сочинения Ф. Шиллера и др.

Не умаляя достоинств каждого из руководителей училища, позволим выделить В.А. Потто (1836-1911), который в течение 11 лет не только управлял этим учебным заведением и много сделал для образования и воспитания учащихся, но также являлся пропагандистом книги и чтения в военной среде города.
В Оренбург В.А. Потто прибыл уже будучи известным военным писателем, автором «Воспоминаний о Закавказском походе 1853-1856 г.», «Истории Новороссийского драгунского полка 1803-1865» и ряда других произведений.

Находя нужным подготовить юнкеров к службе именно в степи и преследуя цель неразрывности образования и будущей службы, В.А. Потто написал книгу «О степной войне», предполагая ввести данный предмет в курс обучения. «600 экземпляров означенного сочинения, напечатанного на счет хозяйственных сумм училища, сданы мною в библиотеку училища и будут служить учебниками, а также будут раздаваться в собственность юнкерам при выпуске их в офицеры, - писал Василий Александрович из Оренбурга 8 мая 1872 г. П.О. Бобровскому $(1832-1905)$, занимавшемуся в то время реформой военного образования. - Что же касается до отсылки экземпляров в остальные юнкерские училища, то предполагаю исполнить это в будущем году, когда означенное сочинение будет дополнено новыми сведениями» [25, л. 817-819]. К сожалению, до сих пор не удалось обнаружить ни одного экземпляра первого издания книги.

В том же 1872 г. им были прочитаны публичные лекции «О степных походах», изданные затем в «Военном сборнике» [26] и в 1873 г. отдельной книгой [27]. Работа привлекла внимание коллег $[28 ; 29$, c. 87,96$]$, была встречена лестными отзывами в печати, переведена в Лондоне на английский язык и вышла под названием «Steppe campaigns» в 1874 году [30, c. 66]. Организацию лекций и военных бесед В.А. Потто считал очень важным в образовании офицеров и методику их проведения изложил в работе «Современное образование и воспитание войск», опубликовав ее в «Военном сборнике» [31] и издав отдельной книгой в Оренбурге [32] и Санкт-Петербурге [33]. Он писал: «С повсеместным открытием офицерских собраний и библиотек, является полнейшая возможность к тому, чтобы путем систематически направленных чтений и военных бесед упрочить в среде офицеров познания, вызываемые современными требованиями службы, и возобновить в их памяти необходимые сведения по тактике. $<\ldots>$ Это легчайший способ познакомить массу наших офицеров с творениями лучших военных писателей, провести в нее известные идеи, и, мало по малу, приучить молодых людей к серьезному и дельному чтению» [32, с. 154-155]. С целью военно-патриотического воспитания В.А. Потто устроил в училище Военно-картинную галерею, собрав более тысячи картин и портретов, составил «Военную хрестоматию», статьи из которой служили темами для бесед с юнкерами [30, с. 66-67].

В декабре 1881 г. В.А. Потто сдал свой пост и покинул город. Его деятельность по управлению училищем получила положительную характеристику в приказе генерала К.М. Войде, бывшего в то время начальником штаба Оренбургского во- 


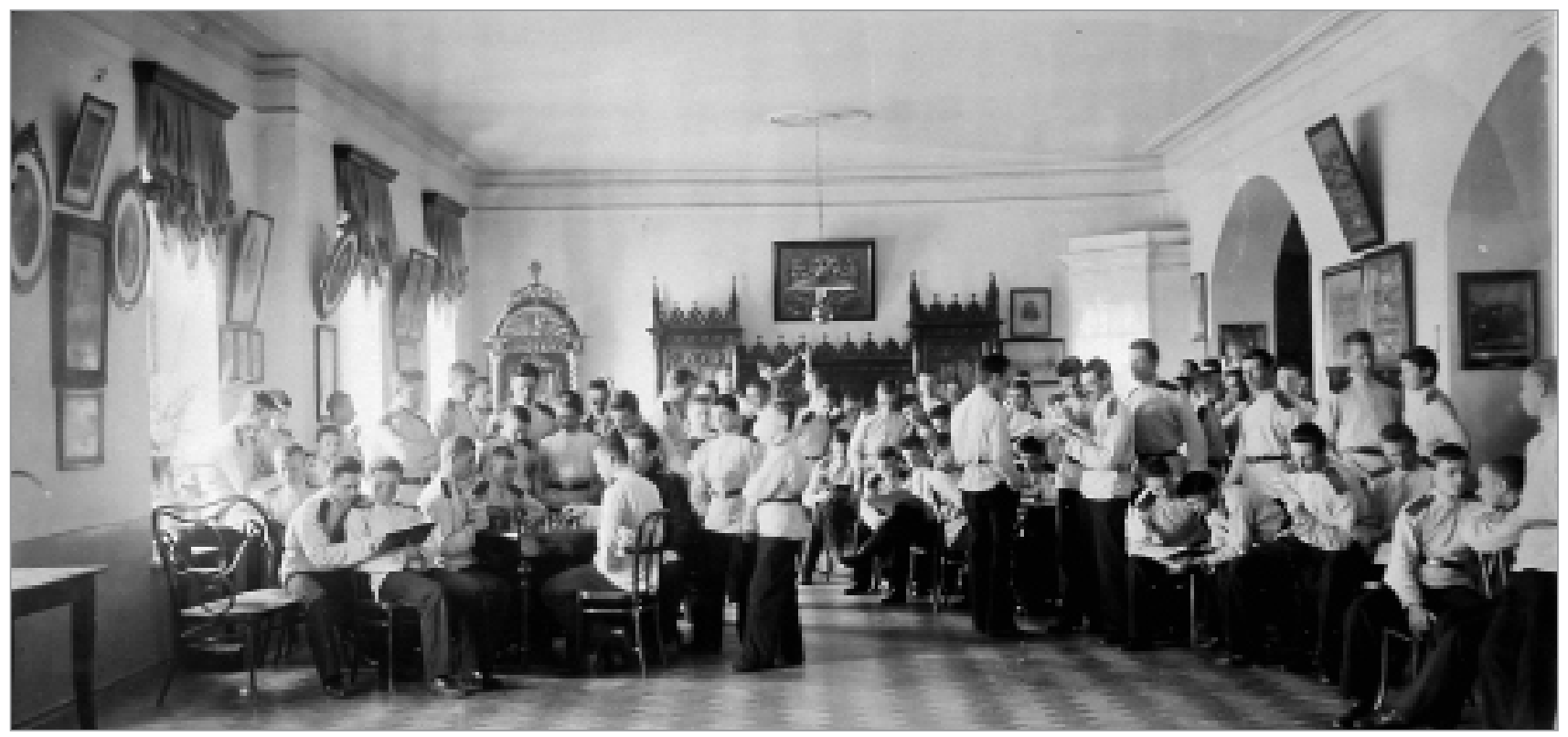

Кадеты 1-й роты Оренбургского Неплюевского кадетского корпуса в рекреационном зале в свободное от занятий время. Фото 1900-х годов

( из фондов Центрального государственного архива кинофотофонодокулентов Санкт-Петербурга)

енного округа, в котором он особо отметил, что «училище роскошно снабжено всякими учебными пособиями» [30, с. 68].

\section{Второй оренбургский кадетский корпус}

29 мая 1887 г. военная прогимназия была преобразована во Второй оренбургский кадетский корпус на 300 воспитанников. Главным назначением его было давать воспитание детям офицеров, служащих в Туркестанском округе [8, с. 50].

Можно с большой долей уверенности предположить, что библиотека военной прогимназии осталась в корпусе.

В 1886 г. вышел новый документ - «Инструкция по воспитательной части для кадетских корпусов», затем переиздававшаяся в 1886, 1904, 1908 годах. В ней был представлен порядок организации внеклассного чтения воспитанников, как самостоятельно, так и с офицерами-воспитателями, обязанности воспитателя отделения относительно нравственного воспитания, в том числе и чтения [34].

В книге «Второй оренбургский кадетский корпус (1887-1894) в ряду других военно-учебных заведений», указывается, что в данном учебном заведении кадетам советовалось заводить тетради и заносить в них краткое содержание прочитанного, отмечалось, что кадетам нравилось читать книги о войне, военном быте, о путешествиях, «в особенности фантастические рассказы Жюля Верна» [8, с. 62, 65]. Чтение воспитателей также не оставалось без внимания руководства. Они могли читать как основываясь на собственном выборе, так и по рекомендации учителей, а затем докладывали о прочитанной литературе на заседаниях педагогического комитета [8, с. 65]. Эти данные могут служить доказательством того, что названные нормативные документы применялись в работе библиотек и руководстве чтением.

Фундаментальная библиотека корпуса содержала в 1891 г. 3090 томов, в 1894 г. - 967 названий книг (3512 томов). Ротные (для внеклассного чтения) библиотеки «щедро снабжались книгами по всем отраслям» и в 1891 г. имели 754 названия книг, в 1894 г. - 804 в 1178 томах. Библиотеки учебников и учебных пособий (карт, атласов, глобусов) в 1891 г. располагали 3462 томами учебников, в $1894-6100$ томами (191 название) [8, с. $67 ; 22$, с. $112-116$ ].

\section{Оренбургская школа прапорииков пехоты}

В связи с началом Первой мировой войны, повлекшим большие потери офицеров, в ряду мер по усилению подготовки командных кадров было принято решение об открытии в 1915 г. в России школ прапорщиков. Приказом от 20 июля 1915 г. такая школа (на 500 человек) была создана и в Оренбурге. Срок обучения сначала составлял три месяца, затем - четыре. Сведений об этом военном учебном заведении историками практически не обнаружено, за исключением общих статистических.

Известно, что школа прапорщиков занимала почти все двухэтажное здание мужской гимназии. Воспитанники в течение всего года учились во вторую смену в здании Первой женской гимназии, причем туда были переведены все ее «учебно-вспомогательные учреждения», кроме фундаментальной библиотеки, оставшейся на прежнем месте [35]. Оренбургская школа прапорщиков пехоты была ликвидирована в 1918 году. 
Учитывая такой напряженный график подготовки, можно предположить, что библиотеки как таковой в школе прапорщиков не имелось.

\section{Судьба библиотек военно-учебных заведений Оренбурга}

Во время Гражданской войны Оренбург несколько раз переходил то к отрядам Красной армии, то к войску атамана А.И. Дутова, что не могло не отразиться на состоянии культурного наследия города, в том числе и библиотечных фондов.

В 1917 г. в здании Оренбургского юнкерского училища некоторое время находился штаб Оренбургского казачьего войска, оборонявшийся от наступавших войск красных. В феврале 1918 г. Оренбург пал, и начальник училища генералмайор К.М. Слесарев увел юнкеров в Уральск. Летом, когда город снова перешел во власть казачьих войск, 20-25 юнкеров младшего курса и кадры училища вернулись в Оренбург [36]. 6 июля 1918 г. председатель Оренбургской ученой архивной комиссии А.В. Попов (1867-1928) писал войсковому атаману А.И. Дутову: «Во время вторжения в город большевиков сначала матросами, а потом красноармейцами было разграблено множество библиотек и музеев, в том числе музей и библиотека Военного казачьего училища» [37]. В январе 1918 г., при отходе белых частей, здание Оренбургского кадетского корпуса сгорело, и в нем погибли «очень ценная библиотека, физический кабинет и лаборатория» [38].

В 1919 г. Казачье юнкерское училище и оба кадетских корпуса оказались в Иркутске, где в январе 1920 г., после установления там советской власти, прекратили свое существование.

Оставшиеся книги из разоренных библиотек закрытых учреждений и организаций, а также реквизированные из частных библиотек в конце 1918 г. попали в книжный склад. Оттуда лучшие книги были выделены для организации научной читальни, остальные распределены между библиотеками города и уезда [39].

В настоящее время небольшие коллекции книг из библиотек оренбургских кадетских корпусов имеются в Оренбургской областной универсальной научной библиотеке (ОУНБ) им. Н.К. Крупской, книги духовного содержания из библиотеки Оренбургского Неплюевского кадетского корпуса - в библиотеке Оренбургского областного музея изобразительных искусств.

Автор выражает глубокую признательность библиотекарю Оренбургского областного музея изобразительных искусств Т.В. Майданюк и сотрудникам ОУНБ им. Н.К. Крупской И.А. Калашниковой, В.М. Капустиной и Т.В. Медведевой за предоставленную возможность поиска книг военно-образовательных учреждений Оренбурга.

\section{Список источников}

1. Государственный архив Оренбургской области (ГАОО). Ф. 96. Оп. 1. Д. 95. Л. 156 об.

2. Рязанов А.Ф. Научно-историческое и культурное значение Оренбургского губернского архива // Вестник просвещенца. Оренбург, 1927. № 9-10. С. 52.

3. Кирилов И. Роспись инструментам и книгам // Материалы для истории Императорской Академии наук. Санкт-Петербург, 1886. Т. 2. С. 495.

4. Сафронова А.М. Оренбургская коллекция иностранных книг в составе библиотеки Горного ведомства Екатеринбурга // Известия Уральского федерального университета. Сер. 2. Гуманитарные науки. 2010. T. 76, № 2. C. 90.

5. Соловьев С.М. История России с древнейших времен. 2-е изд. Санкт-Петербург, 1897. T. XXVIXXIX, кн. шестая. С. 256-257.

6. Военные кантонисты [Электронный ресурс] // Челябинская область. Энциклопедия Челябинской области. URL: http://chel-portal.ru/?site= encyclopedia\& $\mathrm{t}=$ voennye-kantonisty\&id $=4053$ (дата обращения: 12.08.2016).

7. Российский государственный военно-исторический архив (РГВИА). Ф. 1754.

8. Второй оренбургский кадетский корпус (1887-1894) в ряду других военно-учебных заведений. СанктПетербург : Тип. М.М. Стасюлевича, 1894.80 с.

9. Государственный архив Оренбургской области (ГАОО). Ф. 233. Оп. 1. Д. 24. Л. 6, 8, 12.

10. Об учреждении в Оренбурге училища под названием Неплюевского // Азиатский вестник с 1 июля по дек. 1825 г. Санкт-Петербург : Тип. мед. департамента МВД, $1825.410 \mathrm{c}$.

11. Бондаренко M.A. Библиотеки военно-учебных заведений XVIII - начала XX в. и их роль в формировании офицеров русской армии // Библиосфера. 2012. № 3. C. $18-25$.

12. Санкт-Петербургский филиал архива Российской академии наук (СПФ АРАН). Ф. 158. Оп. 4. Д. 13.

13. Матвиевская Г.П. Становление Оренбургского Неплюевского военного училища (1825-1832 гг.) [Электронный ресурс] // Вестник Оренбургского государственного педагогического университета : электронный научный журнал. 2016. № 2 (18). C. 167-186. URL: http://vestospu.ru/archive/2016/ articles/18_18_2016.pdf (дата обращения: 12.08.2016).

14. Государственный архив Оренбургской области (ГАОО). Ф. 6. Оп. 10.

15. Лобысевич Ф.И. Город Оренбург : историко-статистический очерк. Санкт-Петербург: Тип. Эдуарда Гоппе, 1878.59 c.

16. Циркуляр по военно-учебным заведениям. 16 декабря. 1866. № 50 // Педагогический сборник. 1867. № 1. C. $39-43$.

17. Седова E.E., Пономарева С.В. Чтение в системе воспитания кадетских корпусов // Историко-педагогический журнал : электронная версия. 2014. № 4. C. 103-113. URL : https://www.ntspi.ru/ipj/ archive 1 15.\% 20ИПжурнал-4, \% 202014.pdf (дата обращения: 12.08.2016).

18. Инструкция по содержанию библиотек военноучебных заведений, подведомственных Главному их управлению // Педагогический сборник. 1882. № 2. C. $19-31$. 
19. Положение о кадетских корпусах, высочайше утвержденное 14 февраля 1886 г. Санкт-Петербург : Тип. М.М. Стасюлевича, 1886.94 с.

20. География генеральная, небесный и земноводный круги, купно с их свойствы и действы, в 3 томах описующая. Сочинения доктора медицины Берн. Варения / переведена на русский язык в Москве повелением царского пресветлого величества в 1718 году. Москва, 1718. 15 л., [4], 647 с.

21. Судебник государя царя и великого князя Иоанна Васильевича, и некоторые сего государя и ближних его преемников Указы / собранные и примечаниями изъясненные покойным тайным советником и астраханским губернатором, Васильем Никитичем Татищевым. Москва : при Императорском университете, 1768. [4], 138, [14] с.

22. Белавин К.A. Оренбург. Географо-статистический очерк. Оренбург : Тип. И.И. Ефимовского-Мировицкого, 1891. $127 \mathrm{c.}$

23. Райский П.Д. Путеводитель по городу Оренбургу с очерком его прошлого и настоящего, с иллюстрациями и планом. Оренбург : Оренбургское книжное издательство, 2000. $176 \mathrm{c.}$

24. Оренбургский казачий альбом / авт.-сост. В.Г. Семенов, В.П. Семенова. Оренбург : Димур, 2012. 384 с.

25. Отдел рукописей Российской национальной библиотеки (ОР РНБ). Ф. 80. Д. 5.

26. Потто В.А. О степных походах. Публичные лекции, читанные при Оренбургском юнкерском училище, в 1872 г. // Военный сборник. 1873. № 4. С. 229-266 ; № 5. С. $5-356$; № 6 . С. $209-236$; № 7. С. $33-62$.

27. Потто B.A. О степных походах. Публичные лекции, читанные при Оренбургском юнкерском училище, в 1872 г. Санкт-Петербург : Тип. Департамента уделов, $1873.127 \mathrm{c}$.

28. Юр-Ко. Взгляд на степную войну // Военный сборник. 1873. № 11. С. $49-77$; № 12. С. $219-256$.
29. Вогак C. Киргизская лошадь // Военный сборник. 1873. № 9. C. $87-100$.

30. Краткая летопись военной и литературной деятельности Василия Александровича Потто // В память пятидесятилетнего юбилея военно-литературной деятельности г.-л. В.А. Потто. Посвящается всем друзьям и почитателям юбиляра. Тифлис : Тип. Т-ва «Либерман и Ко», 1909. С. 57-77.

31. Потто В.A. Современное образование и воспитание войск // Военный сборник. 1875. № 11. С. 49-89; № 12 . C. $413-471$.

32. Потто В.A. Современное образование и воспитание войск: беседы с юнкерами Оренбургского юнкерского училища. Оренбург : Тип. Ив.Ив. ЕвфимовскогоМировицкого, 1875. $163 \mathrm{c.}$

33. Потто В.А. Современное образование и воспитание войск : издание журн. «Военный сборник». СанктПетербург : Тип. Департамента уделов, 1875. 102 с.

34. Инструкция по воспитательной части для кадетских корпусов [Электронный ресурс]. URL: http:// www.ruscadet.ru/history/doc/instr-0.htm (дата обращения: 12.08.2016).

35. Государственный архив Оренбургской области (ГАОО). Ф. 79. Оп. 1. Д. 254. Л. 7.

36. Оренбургское казачье училище [Электронный реcypc]. URL: https://ru.wikipedia.org/wiki/Opeнбургское_казачье_училище (дата обращения: 12.08.2016).

37. Государственный архив Оренбургской области (ГАОО). Ф. 96. Оп. 1. Д. 95. Л. 156 об.

38. Рязанов А.Ф. Исторический Оренбург // Вестник просвещенца. 1928. № 4. С. 11 [оттиск].

39. Калскова T.A. От городской общественной библиотеки до областной научной // По волне нашей памяти. Оренбург, 2013. С. 47-48.

Иллюстративный материал предоставлен авторол статьи

\section{Libraries and Reading in the Military Schools of Orenburg (the middle of the 18th century - 1918)}

Tatiana N. Savinova,

Institute of Steppe of the Ural Branch of the Russian Academy of Sciences, 11 Pionerskaya Str., Orenburg, 460000, Russia

E-mail: anaitat2009@yandex.ru

Abstract. From the middle of the 18th century till 1918 Orenburg was a major military centre that in many respects defined its socio-cultural space. Training of personnel for local offices and service in garrison was carried out during that time by several military educational institutions in the city. Due to the historical circumstances, so far have survived not many documents telling both about educational institutions themselves and on their educational support divisions, including libraries. The aim of this work is generalization of the currently available materials on the history of libraries of the military schools of Orenburg. Some of the documents are introduced for scientific use for the first time.

Key words: Military-Educational Institutions, Libraries of Military Schools of Orenburg, History of Libraries, Orenburg School of Military Cantonists, Orenburg Neplyuevsky Cadet Corps, the Second Orenburg Cadet Corps, Orenburg Cossack Junker School, Orenburg School of Infantry Ensigns. 
Citation: Savinova T.N. Libraries and Reading in the Military Schools of Orenburg (the middle of the 18th century - 1918), Bibliotekovedenie [Library and Information Science], 2017, vol. 66, no. 1, pp. 77-86.

Acknowledgements: The author expresses the deep gratitude to T.V. Maydanyuk, librarian of the Orenburg Regional Museum of Fine Arts, and to I.A. Kalashnikova, V.M. Kapustina and T.V. Medvedeva, employees of the Regional Universal Scientific Library named after N.K. Krupskaya, for the opportunity of book search in the Military-educational institutions of Orenburg.

\section{References}

1. Gosudarstvennyi arkhiv Orenburgskoi oblasti (GAOO) [The State Archive of the Orenburg Region], coll. 96, aids 1 , fol. 95 , p. 156 back.

2. Ryazanov A.F. Nauchno-istoricheskoe i kul'turnoe znachenie Orenburgskogo gubernskogo arkhiva [Scientific and Historical and Cultural Significance of the Orenburg Provincial Archive], Vestnik prosveshchentsa [Bulletin of Teachers]. Orenburg, 1927, no. 9-10, p. 52.

3. Kirilov I. Rospis' instrumentam i knigam [Painting Tools and Books], Materialy dlya istorii Imperatorskoi Akademii nauk [Materials for the History of the Imperial Academy of Sciences]. St. Petersburg, 1886, vol. 2, p. 495.

4. Safronova A.M. Orenburgskaya kollektsiya inostrannykh knig v sostave biblioteki Gornogo vedomstva Ekaterinburga [The Orenburg Collection of Foreign Books in the Library of the Mining Department of Yekaterinburg], Izvestiya Ural'skogo federal'nogo universiteta. Ser.2. Gumanitarnye nauki [News of the Ural Federal University. Series 2. Humanities], 2010, vol. 76 , no. 2 , p. 90.

5. Solovyov S.M. Istoriya Rossii s drevneishikh vremen [History of Russia from the Earliest Times]. St. Petersburg, 1897, vol. XXVI-XXIX, book sixth, pp. 256-257.

6. Voennye kantonisty [Military Cantonists], Chelyabinskaya oblast'. Entsiklopediya Chelyabinskoi oblasti [The Chelyabinsk Region. Encyclopedia of the Chelyabinsk Region]. Available at: http:// chel-portal.ru/?site=encyclopedia\&t=voennyekantonisty\&id=4053 (accessed 12.08.2016).

7. Rossiiskii gosudarstvennyi voenno-istoricheskii arkhiv (RGVIA) [The Russian State Military-Historical Archive], coll. 1754 , aids 1 , fol. 155 .

8. Vtoroi orenburgskii kadetskii korpus (1887-1894) $v$ ryadu drugikh voenno-uchebnykh zavedenii [The Second Orenburg Cadet Corps (1887-1894) in the Number of Other Military Educational Institutions]. St. Petersburg, M.M. Stasyulevicha Publ., 1894, $80 \mathrm{p}$.

9. Gosudarstvennyi arkhiv Orenburgskoi oblasti (GAOO) [The State Archive of the Orenburg Region], coll. 233, aids 1 , fol. 24 , p. $6,8,12$.

10. Ob uchrezhdenii v Orenburge uchilishcha pod nazvaniem Neplyuevskogo [On the Establishment of the Neplyuev Orenburg Military School], Aziatskii vestnik $s 1$ iyulya po dek. 1825 g. [Asian Herald from 1 July to December 1825]. St. Petersburg, Meditsinskogo Departamenta MVD Publ., 1825, 410 p.

11. Bondarenko M.A. Biblioteki voenno-uchebnykh zavedenii XVIII - nachala XX v. i ikh rol' v formirovanii ofitserov russkoi armii [Libraries of Military Schools of the 18th - Beginning of 20th Century and Their
Role in Educating Russian Army Officers], Bibliosfera [Bibliosphere], 2012, no. 3, pp. 18-25.

12. Sankt-Peterburgskii filial arkhiva Rossiiskoi akademii nauk (SPF ARAN) [St. Petersburg Branch of the Archive of the Russian Academy of Sciences], coll. 158, aids 4 , fol. 13 , p. 89 back.

13. Matvievskaya G.P. Stanovlenie Orenburgskogo Neplyuevskogo voennogo uchilishcha (1825-1832 gg.) [Neplyuev Orenburg Military School (1825-1832)], Vestnik Orenburgskogo gosudarstvennogo pedagogicheskogo universiteta. Elektronnyi nauchnyi zhurnal [Vestnik of Orenburg State Pedagogical University. Electronic Scientific Journal], 2016, no. 2 (18), pp. 167-186. Available at: http://vestospu. $\mathrm{ru} /$ archive/2016/articles/18_18_2016.pdf (accessed 12.08.2016).

14. Gosudarstvennyi arkhiv Orenburgskoi oblasti (GAOO) [The State Archive of the Orenburg Region], coll. 6, aids 10.

15. Lobysevich F.I. Gorod Orenburg: istoriko-statisticheskii ocherk [The City of Orenburg: the Historical and Statistical Essey]. St. Petersburg, Eduarda Goppe Publ., 1878, 59 p.

16. Tsirkulyar po voenno-uchebnym zavedeniyam. $16 \mathrm{de}-$ kabrya. 1866. № 50 [Circular on Military Schools. 16 Dec. 1866. No. 50], Pedagogicheskii sbornik [Pedagogical Collection], 1867, no. 1, pp. 39-43.

17. Sedova E.E., Ponomareva S.V. Chtenie v sisteme vospitaniya kadetskikh korpusov [Reading in the Educational System of the Cadet Corps], Istoriko-pedagogicheskii zhurnal: elektronnaya versiya [Historical and Pedagogical Journal: the Electronic Version], 2014, no. 4, pp. 103-113. Available at: https://www. ntspi.ru/ipj/archive/15. $\% 20 \%$ D0 $\% 98 \%$ D0 $\%$ 9F $\%$ D 0\% B6 \% D1 \% 83\% D1\% 80\% D0\% BD \% D0\% B0\% D0 $\%$ BB-4, \% 202014.pdf (accessed 12.08.2016).

18. Instruktsiya po soderzhaniyu bibliotek voenno-uchebnykh zavedenii, podvedomstvennykh Glavnomu ikh upravleniyu [Instruction on the Upkeep of Libraries of the Military Schools under the Jurisdiction of Their Main Office], Pedagogicheskii sbornik [Pedagogical Collection], 1882, no. 2, pp. 19-31.

19. Polozhenie okadetskikh korpusakh, vysochaishe utverzhdennoe 14 fevralya 1886 g. [The Statute on Cadet Corps, His Imperial Majesty's Edict of February 14th, 1886]. St. Petersburg, M.M. Stasyulevicha Publ., 1886, 94 p.

20. Geografiya general'naya, nebesnyi i zemnovodnyi krugi, kupno sikh svoistvy i deistvy, 3 tomakh opisuyushchaya. Sochineniya doktora meditsiny Bern.Vareniya [Geography General, Describing the Amphibious and Celestial Circles, with their Properties and Effects, in 3 Volumes. The Works of Doctor of Medicine Bernhardus Varenius]. Moscow, 1718, 647 p. 
21. Sudebnik gosudarya tsarya i velikogo knyazya Ioanna Vasil'evicha, i nekotorye sego gosudarya i blizhnikh ego preemnikov Ukazy [Code of Laws of Sovereign Tsar and Grand Prince Ivan Vasilyevich, and Some Decrees of this Sovereign and his Successors]. Moscow, Pri Imperatorskom Universitete Publ., 1768, 138 p.

22. Belavin K.A. Orenburg. Geografo-statisticheskii ocherk [Orenburg. The Geographical and Statistical Essay]. Orenburg, I.I. Efimovskogo-Mirovitskogo Publ., 1891, $127 \mathrm{p}$.

23. Raisky P.D. Putevoditel' po gorodu Orenburgu socherkom ego proshlogo i nastoyashchego, s illyustratsiyami i pla nom [Guide to the City of Orenburg with an Essay of its Past and Present, with Illustrations and a Plan]. Orenburg, Orenburgskoe Knizhnoe Publ., 2000, 176 p.

24. Semenov V.G., Semenova V.P. (eds). Orenburgskii kazachii al'bom [Orenburg Cossack Album]. Orenburg, Dimur Publ., 2012, 384 p.

25. Otdel rukopisei Rossiiskoi natsional'noi biblioteki (OR RNB) [Manuscript Department of the National Library of Russia], coll. 80, fol. 5 .

26. Potto V.A. O stepnykh pokhodakh. Publichnye lektsii, chitannye pri Orenburgskom yunkerskom uchilishche, v 1872 g. [On the Steppe Campaigns. Public Lectures Given at the Orenburg Cadet School in 1872], Voennyi sbornik [Military Collection], 1873, vol. 90, no. 4 , pp. $229-266$, vol. 91 , no. 5 , pp. $5-356$, no. 6 , pp. 209-236, vol. 92, no. 7, pp. 33-62.

27. Potto V.A. O stepnykh pokhodakh. Publichnye lektsii, chitannye pri Orenburgskom yunkerskom uchilishche, $v 1872$ g. [On the Steppe Campaigns. Public Lectures Given at the Orenburg Cadet School in 1872]. St. Petersburg, Departamenta Udelov Publ., 1873, 127 p.

28. Yur-Ko. Vzglyad na stepnuyu voinu [View on the Steppe War], Voennyi sbornik [Military Collection], 1873 , no. 11 , pp. $49-77$, no. 12 , pp. $219-256$.

29. Vogak S. Kirgizskaya loshad' [The Kyrgyz Horse], Voennyi sbornik [Military Collection], 1873, no. 9, pp. $87-100$.

30. Kratkaya letopis' voennoi i literaturnoi deyatel'nosti Vasiliya Aleksandrovicha Potto [Brief Chronicle of the Military and Literary Activities of Vasily Aleksandrovich Potto], V pamyat' pyatidesyatiletnego yubileya voenno-literaturnoi deyatel'nosti g.-l. V.A. Potto. Posvyashchaetsya vsem druz'yam i po- chitatelyam yubilyara [In Memory of the Fiftieth Anniversary of the Military and Literary Activities of Lieutenant General V.A. Potto. Dedicated to All his Friends and Admirers]. Tiflis, Tovarishchestva "Liberman i Ko" Publ., 1909, pp. 57-77.

31. Potto V.A. Sovremennoe obrazovanie i vospitanie voisk [Modern Education and Training of Troops], Voennyi sbornik [Military Collection], 1875, no. 11, pp. 49-89, no. 12 , pp. 413-471.

32. Potto V.A. Sovremennoe obrazovanie i vospitanie voisk: besedy s yunkerami Orenburgskogo yunkerskogo uchilishcha [Modern Education and Training of Troops: Conversations with Cadets of the Orenburg Cadet School]. Orenburg, Iv.Iv. Evfimovskogo-Mirovitskogo Publ., 1875, $163 \mathrm{p}$.

33. Potto V.A. Sovremennoe obrazovanie i vospitanie voisk [Modern Education and Training of Troops], Voennyi sbornik [Military Collection]. St. Petersburg, Departamenta Udelov Publ., 1875, 102 p.

34. Instruktsiya po vospitatel'noi chasti dlya kadetskikh korpusov [Manual for Educational Affairs for Cadet Corps]. Available at: http://www.ruscadet.ru/ history/doc/instr-0.htm (accessed 12.08.2016).

35. Gosudarstvennyi arkhiv Orenburgskoi oblasti (GAOO) [The State Archive of the Orenburg Region], coll. 79, aids 1 , fol. 254 , p. 7.

36. Orenburgskoe kazach'e uchilishche [The Orenburg Cossack School]. Available at: https://ru.wikipedia.org/wi $\mathrm{ki} / \% \mathrm{D0} \%$ 9E $\%$ D1 $\%$ 80 $\%$ D0 $\%$ B5 $\%$ D0 $\%$ BD $\%$ D0 $\%$ B1 $\%$ D1 $\% 83 \%$ D1 $\%$ 80\% D0 $\%$ B3 $\%$ D1 $\% 81 \%$ D0 $\%$ BA $\%$ D 0\% BE $\%$ D0 $\%$ B5_\% D0 $\%$ BA $\%$ D0 $\%$ B0 $\%$ D0 $\%$ B7\% D0 $\%$ B0 $\%$ D1 $\%$ 87\% D1 \% 8C $\%$ D0 $\%$ B5 \% D1 \% 83\% D1 \%

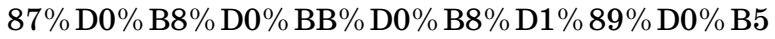
(accessed 12.08.2016).

37. Gosudarstvennyi arkhiv Orenburgskoi oblasti (GAOO) [The State Archive of the Orenburg Region], coll. 96, aids 1 , fol. 95, p. 156 back.

38. Ryazanov A.F. Istoricheskii Orenburg [Historical Orenburg], Vestnik prosveshchentsa [Bulletin of Teachers], 1928, no. 4, p. 11.

39. Kamskova T.A. Ot gorodskoi obshchestvennoi biblioteki do oblastnoi nauchnoi [From a Public Library to a Regional Scientific One], Po volne nashei pamya$t i$ [On the Wave of our Memory]. Orenburg, 2013, pp. $47-48$. 